\title{
EFFECTS OF SALINITY AND SHAKING CONDITION ON THE GROWTH AND VIRULENCE OF VIBRIO PARAHAEMOLYTICUS
}

\author{
Tran Ngoc My Hanh, Tran Van Nhi, Nguyen Thi Thu Hoai ${ }^{凶}$ \\ Ho Chi Minh City International University, Vietnam National University Ho Chi Minh City \\ ${ }^{\circledR}$ To whom correspondence should be addressed. E-mail: ntthoai@hcmiu.edu.vn
}

Received: 05.3.2020

Accepted: 18.4.2020

\section{SUMMARY}

Vibrio parahaemolyticus is a Gram-negative halophilic bacterium that is found in estuarine, marine and coastal environment. This organism is the major causative agent of Early Mortality Syndrome (EMS) or Acute Hepatopancreatic Necrosis Disease (AHPND) which resulted in serious damages to cultured shrimp industry. Understanding the effect of environmental factors on the growth and virulence of this potential pathogen would be beneficial for preventing its outbreak. In this study, the growth and virulence of $V$. parahaemolyticus was examined under different salinity and shaking condition. V. parahaemolyticus XN9 was cultured in Brain Heart Infusion (BHI) medium with different sodium chloride concentrations $(2.0,2.5$ and $3.0 \%)$ and different shaking conditions $(0,120$ and $240 \mathrm{rpm}$ ). The growth of the bacterium was recorded over $8 \mathrm{~h}$ and six extracellular enzymes of $V$. parahaemolyticus XN9 including caseinase, hemolysin, lecithinase, lipase, gelatinase, chitinase were investigated using agar-based method. The growth of $V$. parahaemolyticus was varied among different salinity and shaking conditions. It showed the best growth at $2.0 \% \mathrm{NaCl}$ and $240 \mathrm{rpm}$. No change in the enzymatic activity (EA) of the tested extracellular enzymes was observed while changing salinity except the significant decline of gelatinase from $3.49 \pm 0.19$ to $2.77 \pm 0.17 \mathrm{~mm}$ following salinity increase $(\mathrm{p}<0.05)$. On the other hand, regarding shaking condition, lipase was the one to increase its activity significantly following the increase of shaking speed $(\mathrm{p}<0.05)$. While caseinase, lecithinase, gelatinase and lipase were well expressed in $V$. parahaemolyticus, no hemolytic and chitinase activity was observed in any tested conditions. In summary, our study showed that $2.0 \% \mathrm{NaCl}$ and $240 \mathrm{rpm}$ shaking promoted the best growth of $V$. parahaemolyticus and resulted in highest activity of gelatinase and lipase in this bacterium.

Keywords: Vibrio parahaemolyticus, Acute Hepatopancreatic Necrosis Disease (AHPND); extracellular enzymes, growth, salinity, shaking condition, virulence

\section{INTRODUCTION}

Vibrio parahaemolyticus is a member of Vibrio species from the Vibrionaceae family. $V$. parahaemolyticus is a Gram-negative, halophilic bacterium that can be found in estuarine, marine and coastal environment as a free organism or parasite of zooplankton, fish, shellfish and shrimp (Ceccarelli et al., 2013). This motile bacterium can also be a human pathogen causing food-borne illness such as gastroenteritis with the symptoms involving nausea, vomiting, abdominal pain and diarrhea which is often associated with consuming raw or undercooked seafood (Shinoda, 2011). Furthermore, Vibrio parahaemolyticus has been reported to be the major causative agent of Early Mortality Syndrome (EMS) or Acute Hepatopancreatic Necrosis Disease (AHPND) (Tran et al., 2013). $V$. parahaemolyticus colonizes the shrimp gastroenteritis tract and is transmitted orally. It produces toxins causing tissue destruction, 
dysfunction of the shrimp digestive organ known as the hepatopancreas and death in the first 30 days after stocking (Lai et al., 2015). AHPND was firstly appeared in southern China (2009) then spread quickly over to Hainan Island (2010), Viet Nam (2010), Malaysia (2011) and Thailand (2012), Mexico (2013), the Philippines (2015) and South America (2016) which affected heavily shrimp industry leading to significant global economic loss (Li et al., 2017). In general, the bacterium uses multiple virulence factors in its pathogenesis such as adhesins, hemolysin, urease, type III and type VI secretion systems (Wang et al., 2015; Letchumanan et al., 2014). Other extracellular enzymes such as protease, lipase, lecithinase even though are well noted as virulence factors contributing significant to the pathogenesis in Vibrio species, they are not well studied in V. parahaemolyticus (Miyoshi, 2013; Li et al., 2019; Zhang et al., 2016; Xiong et al., 2014). So far, while hemolysins such as thermostable direct hemolysin $(t d h)$ and TDHrelated hemolysin (trh) are usually characterized as important virulence factors of $V$. parahaemolyticus in human enteritis, plasmidencoded binary toxins $\operatorname{PirA}^{\mathrm{vp}} / \mathrm{PirB}^{\mathrm{vp}}$ are the noted ones for AHPND (Letchumanan et al., 2014). Besides, it is well noted that host and environmental factors have strong impact on the expression of bacterial virulence factors (Do et al., 2019; Figueroa-Angulo et al., 2012; Kumar et al., 2019). In case of $V$. parahaemolyticus, a marine and estuarine bacterium, it is no doubt that its growth as well as virulence is greatly influenced by dissolve oxygen and salinity. Effect of salinity on growth of different $V$. parahaemolyticus strains has been long studied. Data indicated that most of the strains can grow in the range of 1-9\% $\mathrm{NaCl}$ but have optimal salinity of 2-3\% (Liu et al., 2016; Whitaker et al., 2010; Nishina et al., 2004). Dissolved oxygen or its associate, shaking condition has not been as well studied as salinity but recent data indicated that virulence of $V$. parahaemolyticus cultured at $120 \mathrm{rpm}$ was significantly higher than at $110 \mathrm{rpm}$ towards Artemia and Macrobrachium larvae (Kumar et al., 2019).
In this study, we investigated how $V$. parahaemolyticus XN9, an AHPND-causing isolate responded to different salinities and shaking conditions via observing its growth and production of its virulence factors including the noted six extracellular enzymes including caseinase, hemolysin, lipase, lecithinase, gelatinase and chitinase.

\section{MATERIALS AND METHODS}

\section{Bacterial strain}

Vibrio parahaemolyticus XN9 was generously provided by Nha Trang University for this study and its identity was again confirmed by our group (Vu et al., 2017). Before testing, $V$. parahaemolyticus XN9 was cultured on Thiosulfate-citrate-bile salts-sucrose agar (TCBS, Himedia, India) overnight, at $30^{\circ} \mathrm{C}$.

\section{Growth analysis of $V$. parahaemolyticus under different $\mathrm{NaCl}$ concentrations and shaking conditions}

V. parahaemolyticus XN9 was optimally maintained and preserved in Brain Heart Infusion (BHI) medium with $2.5 \% \mathrm{NaCl}, 30^{\circ} \mathrm{C}$, pH 8.5 and $120 \mathrm{rpm}$ (Anh et al., 2018). This condition $\left(2.5 \% \mathrm{NaCl}, 30^{\circ} \mathrm{C}, \mathrm{pH} 8.5,120 \mathrm{rpm}\right)$ was applied in this study as standard condition to determine the effect of different salinity and shaking condition on the virulence factors of $V$. parahaemolyticus.

To examine the effect of salinity, a single colony of $V$. parahaemolyticus XN9 was inoculated into BHI broth (Himedia, India) having different salt concentrations, 2.0, 2.5 and $3.0 \%$ and incubated overnight, $120 \mathrm{rpm}$ at $30^{\circ} \mathrm{C}$. In the next day, the bacteria suspension was used to inoculate BHI broth with corresponding salt concentrations. The starting $\mathrm{OD}_{620 \mathrm{~nm}}(0 \mathrm{~h})$ was adjusted to $0.05(0 \mathrm{~h})$ and the flasks were incubated at $30^{\circ} \mathrm{C}, 120 \mathrm{rpm}$ and measured each hour for $\mathrm{OD}_{620 \mathrm{~nm}}$ and dissolved oxygen (DO) concentration for 8 hours.

To examine the effect of shaking condition, same procedure was carried out on $V$. 
parahaemolyticus but instead of varying salinity, salt concentration was kept at $2.5 \%$ and shaking conditions was varied between 0,120 and 240 $\mathrm{rpm}$. The experiments were triplicated.

\section{Extracellular enzymatic activity analysis of $V$. parahaemolyticus under different $\mathrm{NaCl}$ concentrations and shaking conditions}

Caseinase, hemolysin, lipase, lecithinase, gelatinase and chitinase were examined using agar-based method. V. parahaemolyticus XN9 was inoculated and cultured in either BHI broth (Himedia, India) having different salt concentrations, 2.0, 2.5 and $3.0 \%$ overnight at $30^{\circ} \mathrm{C}, 120 \mathrm{rpm}$ to assess to effect of salinity on the extracellular enzyme activity or BHI broth (Himedia, India) $2.5 \% \mathrm{NaCl}$, overnight at $30^{\circ} \mathrm{C}$ at different shaking conditions, 0, 120 and 240 $\mathrm{rpm}$ to assess to effect of salinity on the extracellular enzyme activity. $V$. parahaemolyticus cultured was diluted at $\mathrm{OD}_{620 \mathrm{~nm}}=0.1$ before being applied on agar plates corresponding to each type of extracellular enzyme activity testing. All the media used were adjusted to $\mathrm{pH}$ 8.5. The experiments were triplicated.

- Caseinase test: $10 \mu \mathrm{L}$ suspension of $V$. parahaemolyticus was dropped onto the surface of BHI agar plates containing 1.5\% (w/v) skim milk. Simultaneously, $10 \mu \mathrm{L}$ suspension of Vibrio cholera VCTC2012 was added onto another position of the plate as positive control. Then, the plate was incubated overnight, at $30^{\circ} \mathrm{C}$. After incubation, observed clear halos around the colonies indicated the activity of enzyme, in this case, caseinase (Vermelho et al., 1996).

- Hemolysin test: same procedure was carried on with few modifications. The agar used was Sheep blood agar plates which were prepared from Blood agar base (Himedia, India) and Sheep blood suspension $10 \%$ (Nam Khoa Biotech Company). Vibrio cholera VCTC2012 was also used as positive control. The plate was incubated for $48 \mathrm{~h}$.

- Lipase test: The agar used was tributyrin agar plate which is prepared using Tributyrin oil
(Himedia, India) and Tributyrin agar (Himedia, India). Staphylococcus aureus ATCC 29213 was used as positive control. The plate was incubated for $48 \mathrm{~h}$.

- Lecithinase test: the agar used was Egg-yolk agar plate containing $1 \mathrm{~mL}$ of Egg-yolk Emulsion (Himedia, India) and BHI (Himedia. India). Vibrio cholera VCTC2012 was used as positive control. The plate was incubated for $48 \mathrm{~h}$.

- Gelatinase test: the agar used was BHI agar (Himedia, India) containing $2.0 \%$ gelatin. Vibrio cholera VCTC2012 was used as positive control. The plate was incubated overnight. After incubation, the agar surface was immersed in saturated ammonium sulfate $\left(\left(\mathrm{NH}_{4}\right)_{2} \mathrm{SO}_{4}\right)$ solution. Observed clear halos around the colonies indicated the activity of gelatinase. Saturated ammonium sulfate would cloudy precipitate with the remaining gelatin and form white color plate.

- Chitinase test: the Coloidial Chitin was prepared following previously described procedure (Nagpure et al., 2014). The agar used was BHI agar (Himedia, India) containing 5\% colloidal chitin. Vibrio cholera VCTC2012 was used as positive control. The plate was incubated for 48h. Observed clear halos around the colonies indicated the activity of chitinase (Ohishi et al., 2000).

\section{Data analysis}

The enzymatic activity (EA) was calculated as EA $=\frac{\boldsymbol{D}-\boldsymbol{d}}{\boldsymbol{2}}$, in which $\mathrm{D}$ is diameter of both colony and the zone around colony $(\mathrm{mm}), \mathrm{d}$ is diameter of colony (mm) (Vermelho et al. 1996). The EA is graded as follows: (-) when no visible halo is present, $(+)$ when EA value is limited to 1-2 $\mathrm{mm}$ and (++) when EA value is equal or more than $2 \mathrm{~mm}$ (Vermelho et al. 1996). Each test was done in triplicate and the obtained data were analyzed using one-way ANOVA (Excel software, Microsoft). The means were also analyzed using t-tests $(\mathrm{p}<0.05)$ to compare the variation between the extracellular enzymatic activity of each test and corresponding standard 
condition $(2.5 \% \mathrm{NaCl}, \mathrm{pH} 8.5,120 \mathrm{rpm}$ and $\left.30^{\circ} \mathrm{C}\right)$.

\section{RESULTS}

Effect of salinity on the growth of $V$. parahaemolyticus

When being cultured at different salt concentrations, V. parahaemolyticus XN9 behaved quite similarly, especially for 2.5 and $3.0 \% \mathrm{NaCl}$, with only few differences to be noted in case of $2.0 \% \mathrm{NaCl}$. While $V$. parahaemolyticus XN9 entered stationary phase at $4 \mathrm{~h}$ when being cultured in 2.5 and $3.0 \% \mathrm{NaCl}$, it was one hour delayed in case of $2.0 \% \mathrm{NaCl}$. Furthermore, the growth of $V$. parahaemolyticus in $2.0 \% \mathrm{NaCl}$ was also highest among the three tested salt concentrations, with significant difference to $3.0 \% \mathrm{NaCl}(\mathrm{p}<0.05)$ (Figure 1).

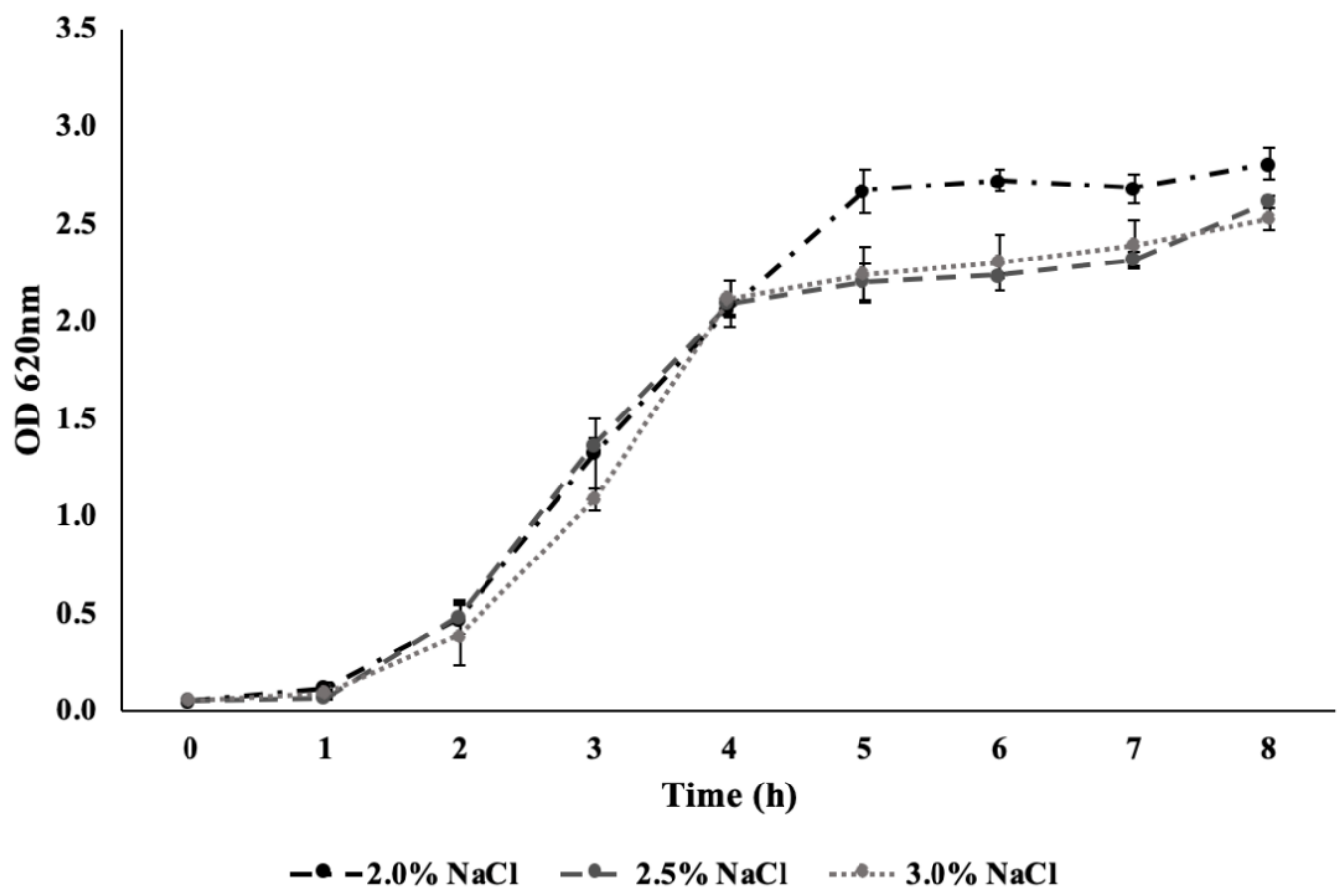

Figure 1. The growth of $V$. parahaemolyticus $\mathrm{XN} 9$ at different $\mathrm{NaCl}$ concentrations $(2.0,2.5$ and $3.0 \%)$. The bacteria were cultured in $\mathrm{BHI}, 120 \mathrm{rpm}, 30^{\circ} \mathrm{C}, \mathrm{pH} 8.5$. The growth was expressed via $\mathrm{OD}_{620 \mathrm{~nm}}$. The experiment was triplicated.

Effect of salinity on extracellular enzymatic activity of $V$. parahaemolyticus

For caseinase and lipase, there was basically no difference in the activity of these enzymes in the three tested salt concentrations. Activity of caseinase was quite low $(1.5 \mathrm{~mm}$, on average) while the activity of lipase was strong $(2.9 \mathrm{~mm}$, on average) for V. parahaemolyticus XN9 (Table 1).

In contrast, gelatinase and lecithinase activity significantly decreased when increasing salinity from 2.0 to $3.0 \% \mathrm{NaCl}(\mathrm{p}<0.05)$ (Table 1). At $2.0 \% \mathrm{NaCl}$, the enzymatic activity was highest for gelatinase $(3.49 \pm 0.19 \mathrm{~mm})$ and lecithinase $(5.06 \pm 0.53 \mathrm{~mm})$ whereas at $3.0 \%$ $\mathrm{NaCl}$, the values were $2.77 \pm 0.17 \mathrm{~mm}$ and 4.22 $\pm 0.27 \mathrm{~mm}$ for gelatinase and lecithinase, respectively.

Interestingly, no activity of hemolysin and chitinase was observed for $V$. parahaemolyticus $\mathrm{XN} 9$ in any tested salt concentrations. 
Journal of Biotechnology 18(2): 349-362, 2020



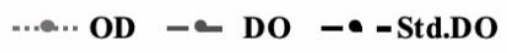

(a)

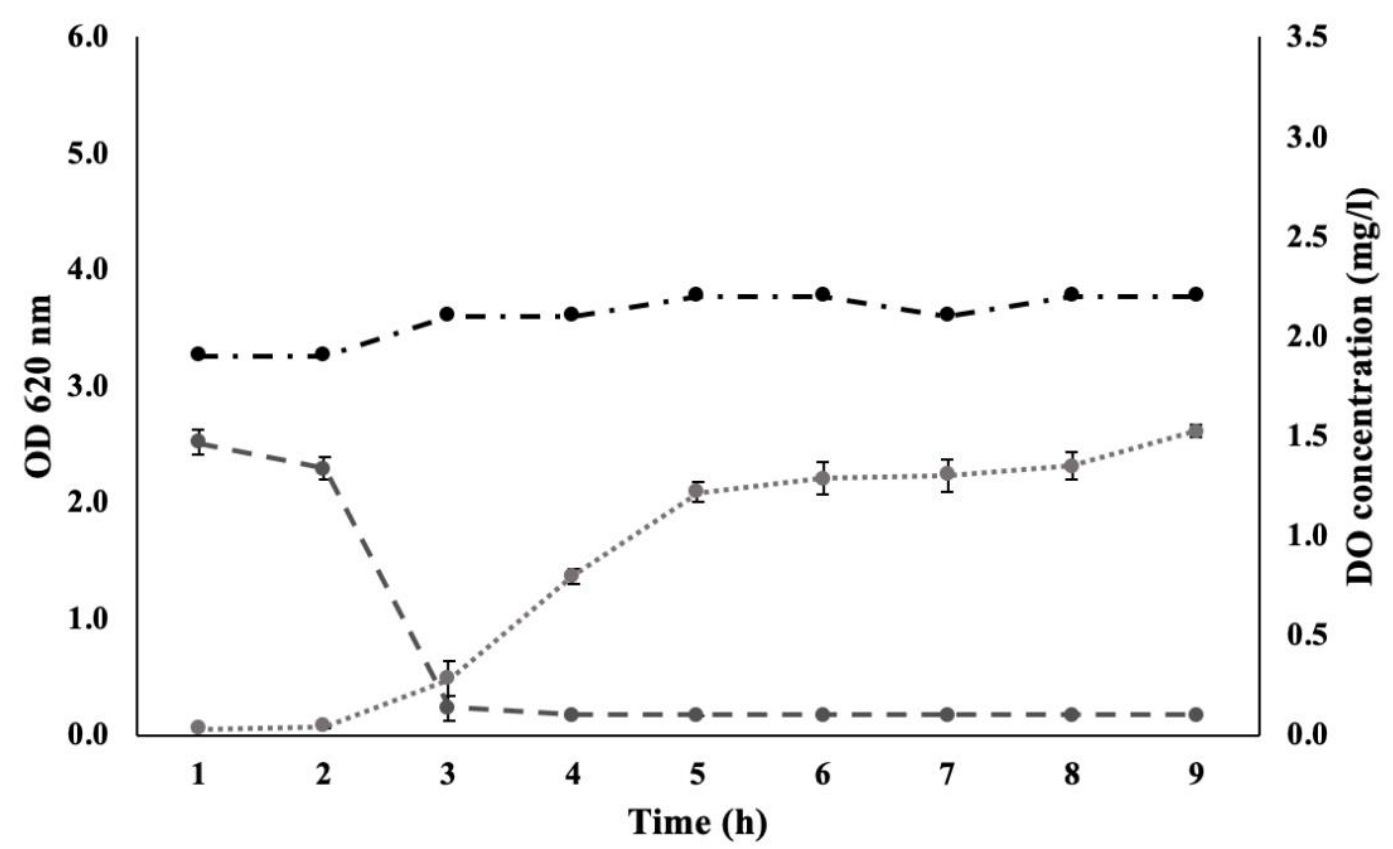

$$
\text { -.... OD -८ DO -•-Std.DO }
$$

(b) 
Tran Ngoc My Hanh et al.

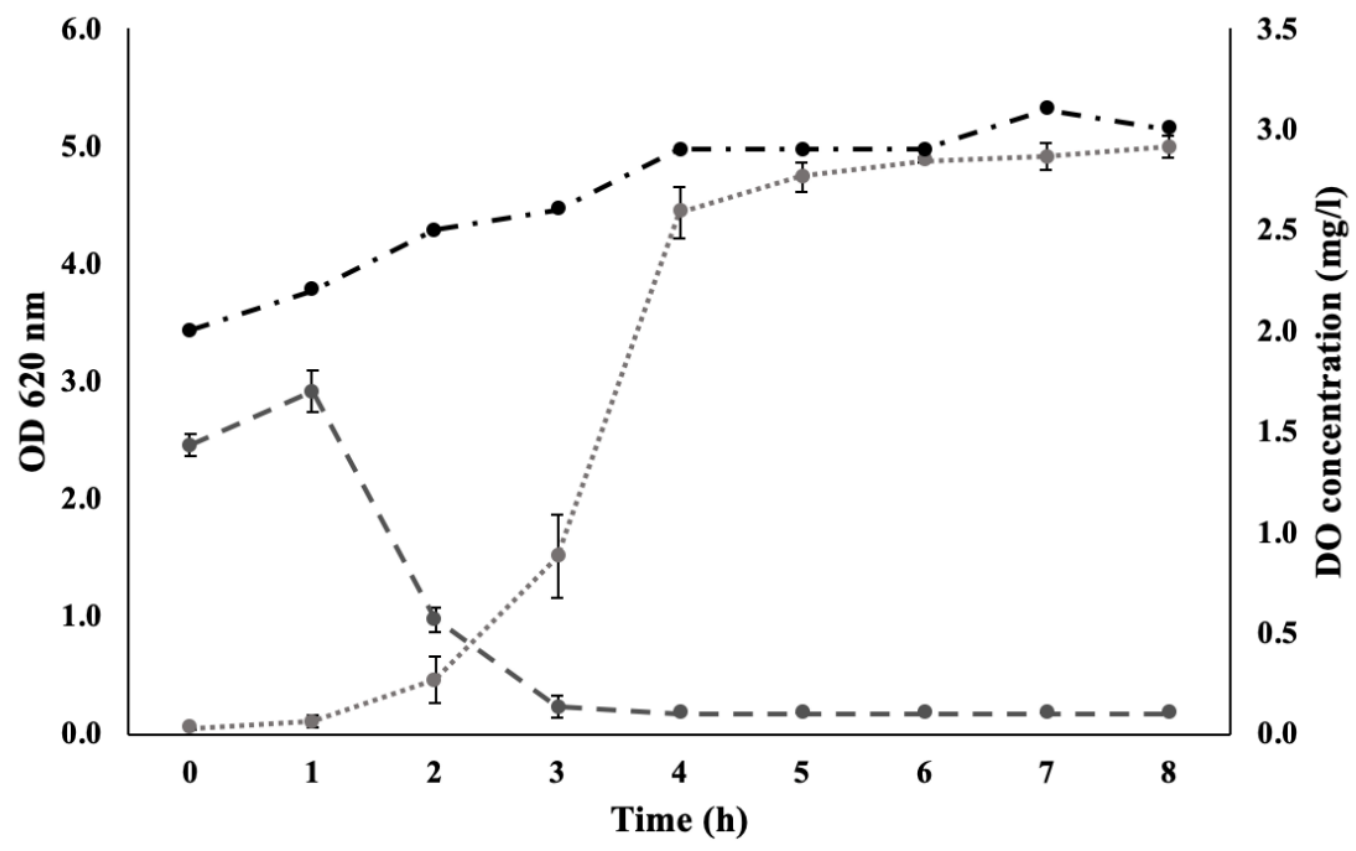

(c)

Figure 2. Growth of $V$. parahaemolyticus under different shaking conditions. (a). at $0 \mathrm{rpm}$, (b). at $120 \mathrm{rpm}$, (c). at $240 \mathrm{rpm}$. The bacteria were cultured in $\mathrm{BHI}$ at $2.5 \% \mathrm{NaCl}, 30^{\circ} \mathrm{C}, \mathrm{pH} 8.5$. The corresponding dissolved oxygen (DO) concentrations were also shown $(\mathrm{mg} / \mathrm{L})$. DO measurement for the control bacteria-free medium flask was represent via Std. DO. The bacterial growth was expressed via $\mathrm{OD}_{620 \mathrm{~nm}}$. The experiment was triplicated.

Table 1. Effect of salinity on extracellular enzymatic activity of $V$. parahaemolyticus XN9. The testing salinity was 2.0, 2.5, 3.0\% and the enzymatic activity EA was shown in millimeters $(\mathrm{mm})$.

\begin{tabular}{|c|c|c|c|c|c|c|}
\hline $\begin{array}{l}\text { Enzymatic } \\
\text { activity (EA) }\end{array}$ & $2.0 \% \mathrm{NaCl}$ & $2.5 \% \mathrm{NaCl}$ & $3.0 \% \mathrm{NaCl}$ & $\begin{array}{l}\text { T-test } \\
\mathrm{T}_{2.0 \%} \text { vs. } \\
\mathrm{T}_{2.5 \%} \text { (p } \\
\text { value) }\end{array}$ & $\begin{array}{l}\text { T-test } \\
\mathrm{T}_{2.5 \%} \text { vs. } \\
\mathrm{T}_{3.0 \%}(\mathrm{p} \\
\text { value) }\end{array}$ & $\begin{array}{l}\text { T-test } \\
\mathbf{T}_{2.0 \%} \text { vs. } \\
T_{3.0 \%}(p \\
\text { value) }\end{array}$ \\
\hline & $1.56 \pm 0.20(+)$ & $1.47 \pm 0.31(+)$ & $1.55 \pm 0.05(+)$ & 0.609 & 0.727 & 0.981 \\
\hline $\begin{array}{l}\text { Lecithinase } \\
\text { (mm, grade) }\end{array}$ & $5.06 \pm 0.53(++)$ & $4.64 \pm 0.31(++)$ & $4.22 \pm 0.27(++)$ & 0.084 & 0.335 & 0.211 \\
\hline $\begin{array}{l}\text { Lipase (mm, } \\
\text { grade) }\end{array}$ & $2.89 \pm 0.43(++)$ & $2.97 \pm 0.27(++)$ & $2.81 \pm 0.42(++)$ & 0.838 & 0.627 & 0.872 \\
\hline $\begin{array}{l}\text { Gelatinase } \\
\text { (mm, grade) }\end{array}$ & $3.49 \pm 0.19(++)$ & $3.03 \pm 0.18(++)$ & $2.77 \pm 0.17(++)$ & 0.072 & 0.218 & 0.001 \\
\hline $\begin{array}{l}\text { Hemolysin } \\
\text { (mm, grade) }\end{array}$ & $0 \mathrm{~mm}(-)$ & 0 mm (-) & $0 \mathrm{~mm}(-)$ & None & none & none \\
\hline $\begin{array}{l}\text { Chitinase } \\
\text { (mm, grade) }\end{array}$ & $0 \mathrm{~mm}(-)$ & $0 \mathrm{~mm}(-)$ & 0 mm (-) & None & none & none \\
\hline
\end{tabular}


Effect of shaking conditions on the growth of $V$. parahaemolyticus

The 8-hour bacterial growth in $\mathrm{BHI} 2.5 \%$ $\mathrm{NaCl}, 30^{\circ} \mathrm{C}, \mathrm{pH} 8.5$ and different shaking speeds was presented in Figure 2. As can be seen, there were significant differences in the growth of $V$. parahaemolyticus among 3 treatments of shaking conditions $(\mathrm{p}<0.05)$. The growth of $V$. parahaemolyticus increased over the increase of shaking speed (Figure 2). The DO concentration, as expected was larger in high shaking speed culture compared to the low ones. However, after 3 hours of cultures, there were no difference in
DO concentration among the 3 shaking conditions.

\section{Effect of shaking condition on extracellular} enzymatic activity of $V$. parahaemolyticus

It was observed that lipase activity significantly increased when increasing the shaking condition from 120 to $240 \mathrm{rpm}(\mathrm{p}<0.05)$ while caseinase, lecithinase and gelatinase did not exhibit any significant variations following an increase the shaking speed (Table 2). Just like in the case of salinity, $V$. parahaemolyticus XN9 did not express any hemolysin and chitinase activity (Table 2).

Table 2. Effect of shaking condition on extracellular enzymatic activity of $V$. parahaemolyticus XN9. The testing shaking speed was 0, 120, $240 \mathrm{rpm}$ and the enzymatic activity EA was presented in millimeter (mm).

\begin{tabular}{|c|c|c|c|c|c|c|}
\hline \multirow[t]{2}{*}{$\begin{array}{l}\text { Enzymatic } \\
\text { activity (EA) }\end{array}$} & \multirow[t]{2}{*}{$0 \mathrm{rpm}$} & \multirow[t]{2}{*}{120 rpm } & \multirow[t]{2}{*}{$240 \mathrm{rpm}$} & \multirow{2}{*}{$\begin{array}{l}\text { T-test } \\
\text { between } \\
T_{0} \text { rpm } \\
\text { and } T_{120} \\
\text { rpm ( } p \\
\text { value })\end{array}$} & \multirow{2}{*}{$\begin{array}{l}\text { T-test } \\
\text { between } \\
T_{120} \mathrm{rpm} \\
\text { and } T_{240} \\
\mathrm{rpm}(\mathrm{p} \\
\text { value })\end{array}$} & \multirow{2}{*}{$\begin{array}{l}\text { T-test } \\
\text { between } \\
T_{0} \text { rpm } \\
\text { and } T_{240} \\
\text { ppm }(p \\
\text { value })\end{array}$} \\
\hline & & & & & & \\
\hline $\begin{array}{l}\text { Caseinase } \\
\text { (mm, grade) }\end{array}$ & $1.42 \pm 0.17(+)$ & $1.47 \pm 0.31(+)$ & $1.33 \pm 0.05(+)$ & 0.826 & 0.565 & 0.523 \\
\hline $\begin{array}{l}\text { Lecithinase } \\
\text { (mm, grade) }\end{array}$ & $4.27 \pm 0.55(++)$ & $4.64 \pm 0.31(++)$ & $4.08 \pm 0.38(++)$ & 0.137 & 0.199 & 0.648 \\
\hline $\begin{array}{l}\text { Lipase (mm, } \\
\text { grade) }\end{array}$ & $3.09 \pm 0.18(++)$ & $2.97 \pm 0.27(++)$ & $3.41 \pm 0.27(++)$ & 0.592 & 0.008 & 0.177 \\
\hline $\begin{array}{l}\text { Gelatinase } \\
\text { (mm, grade) }\end{array}$ & $3.22 \pm 0.13(++)$ & $3.03 \pm 0.18(++)$ & $2.98 \pm 0.08(++)$ & 0.388 & 0.765 & 0.06 \\
\hline $\begin{array}{l}\text { Hemolysin } \\
\text { (mm, grade) }\end{array}$ & 0 mm (-) & $0 \mathrm{~mm}(-)$ & $0 \mathrm{~mm}(-)$ & none & none & none \\
\hline $\begin{array}{l}\text { Chitinase } \\
\text { (mm, grade) }\end{array}$ & 0 mm (-) & 0 mm (-) & $0 \mathrm{~mm}(-)$ & none & none & none \\
\hline
\end{tabular}

\section{DISCUSSION}

With ability to live either freely, parasitically or pathogenically, $V$. parahaemolyticus seems to be very flexible and responds actively to its surrounding environment. Understanding how this pathogen responds to different conditions is crucial to understand its pathogenesis. Culture conditions, no doubt, can highly affect the growth as well as the virulence of $V$. parahaemolyticus.

Salt is an absolute requirement for the bacterial survival and production of virulence factors, especially the capacity of causing EMS/AHPND disease in shrimps. Due to its halophilic habitat. $V$. parahaemolyticus is capable of growth at 1.0 to $9.0 \% \mathrm{NaCl}$ (Whitaker et al., 2010). Our previous data indicated that $V$. parahaemolyticus can optimally survive in the 
media (TSB, BHI, LB, MB) containing 2.0 to $3.0 \% \mathrm{NaCl}$ (Anh et al., 2018). In this work, we investigated different salt concentrations for BHI only and it was observed that the growth of $V$. parahaemolyticus was similar between 2.5 and $3.0 \% \mathrm{NaCl}$ condition while significantly different to $2.0 \% \mathrm{NaCl}$. At $2.0 \% \mathrm{NaCl}, V$. parahaemolyticus grew a bit more slowly but reached higher density. Interestingly, at $2.0 \%$ $\mathrm{NaCl}, \quad V$. parahaemolyticus also expressed significantly high activity of gelatinase than in higher salt concentrations $(\mathrm{p}<0.05)$. Other tested extracellular enzymes did not show significant correlation with salinity. Lipase, caseinase and particularly lecithinase were expressed constantly and strongly for $V$. parahaemolyticus in any salinity. Therefore, it can be suggested that the three enzymes are kind of important for the growth and survival of $V$. parahaemolyticus.

The growth and biosynthesis of $V$. parahaemolyticus XN9 were also strongly influenced by different shaking conditions. As expected, the growth of $V$. parahaemolyticus was most limited in case of no shaking. It was quite understandable as suitable shaking speed created more liquid surface area, increasing oxygen transfer to the bacteria culture medium, resulting in the escalation of bacteria growth rate. However, it would be interesting to look at the corresponding DO concentration data in correlation with bacterial growth. It was shown that the differences in DO concentration were remarkable in the first 3 hour of cultures among three shaking conditions, however diminished afterward. It suggested that once the bacteria reached high density, the DO consumption was super quickly and shaking condition could not provide extra visible difference.

Although growth of $V$. parahaemolyticus was clearly different among different shaking condition, the enzymatic activities, in contrast, did not change much except for lipase. Caseinase, gelatinase and lecithinase were still well expressed in different shaking conditions. Lipase activity increased significantly when shaking speed increased from $120 \mathrm{rpm}$ to 240 $\mathrm{rpm}$. In short, shaking at $240 \mathrm{rpm}$ gave the best growth as well as highest lipase activity of $V$. parahaemolyticus.

We did not observe in any case the production of hemolysin and chitinase. That $V$. parahaemolyticus XN9 did not show hemolytic characteristics was predictable as hemolytic activity is much more frequently found in clinical isolates but not environmental ones (Bhowmik et al, 2014). Chitinase, on the other hand, generally plays an important role in the degradation of the crustacean rich biopolymer chitin, converting it into nutrients for marine bacteria (Frederiksen et al., 2013). It is of course not present in all $V$. parahaemolyticus strains (Hirano et al., 2019). However, the absence of chitinase in AHPND V. parahaemolyticus XN9 indicated that chitinase might not be essential in shrimp pathogenesis or induced in vitro.

\section{CONCLUSION}

Our data suggested that salinity and shaking condition are two crucial factors affecting not only the growth but also extracellular enzymatic activity of $V$. parahaemolyticus. For the salinity, $2.0 \% \mathrm{NaCl}$ concentration gave the best growth as well as gelatinase activity of $V$. parahaemolyticus XN9. For the shaking condition, $240 \mathrm{rpm}$ showed the best growth and lipase activity of the bacteria. In general, while caseinase, gelatinase, lecithinase and lipase were constantly expressed in $V$. parahaemolyticus, activity of hemolysin and chitinase was not observed.

Acknowledgements: We would like to thank Assoc. Prof Nguyen Van Duy, Nha Trang University for kindly providing us the bacterial strain, V. parahaemolyticus XN9.

\section{REFERENCES}

Anh PTL, Khang LQ, Thuc NT, Chau DNP, Nguyen TTH (2018) Optimizing conditions for Vibrio parahaemolyticus culture and preservation. 7th International Conference on the Development of Biomedical Engineering in Vietnam, Ho Chi Minh City, Springer: 681-685. 
Bhowmik SK., Pazhani GP, Ramamurthy T (2014) Phylogenetic and in silico functional analyses of thermostable-direct hemolysin and tdh-related encoding genes in Vibrio parahaemolyticus and other Gram-negative bacteria. Biomed Res Int: 576528.

Ceccarelli D, Hasan NA, Huq A, Colwell RR (2013) Distribution and dynamics of epidemic and pandemic Vibrio parahaemolyticus virulence factors. Front Cell Infect Microbiol 3: 97.

Do H, Makthal N, VanderWal AR, Saavedra MO, Olsen RJ, Musser JM, Kumaraswami M (2019) Environmental $\mathrm{pH}$ and peptide signaling control virulence of Streptococcus pyogenes via a quorumsensing pathway. Nat Commun 10(1): 2586.

Figueroa-Angulo EE, Rendon-Gandarilla FJ, PuenteRivera J, Calla-Choque JS, Cardenas-Guerra RE, Ortega-Lopez J, Quintas-Granados LI, AlvarezSanchez ME, Arroyo R (2012) The effects of environmental factors on the virulence of Trichomonas vaginalis. Microbes Infect 14(15): 1411-1427.

Frederiksen RF, Paspaliari DK, Larsen T, Storgaard BG, Larsen MH, Ingmer H, Palcic MM, Leisner JJ (2013) Bacterial chitinases and chitin-binding proteins as virulence factors. Microbiology 159(Pt 5): 833-847.

Hirano T, Okubo M, Tsuda H, Yokoyama M, Hakamata W, Nishio T (2019) Chitin heterodisaccharide, released from chitin by chitinase and chitin oligosaccharide deacetylase, enhances the chitin-metabolizing ability of Vibrio parahaemolyticus. J Bacteriol 201(20).

Kumar V, Roy S, Baruah K, Van Haver D, Impens F, Bossier B (2019) Environmental conditions steer phenotypic switching in acute hepatopancreatic necrosis disease-causing Vibrio parahaemolyticus, affecting PirA(VP) /PirB(VP) toxins production. Environ Microbiol.

Lai HC, Ng TH, Ando M, Lee CT, Chen IT, Chuang JC, Mavichak R, Chang SH, Yeh MD, Chiang YA, Takeyama H, Hamaguchi HO, Lo CF, Aoki T, Wang HC (2015) Pathogenesis of acute hepatopancreatic necrosis disease (AHPND) in shrimp. Fish Shellfish Immunol 47(2): 1006-1014.

Letchumanan V, Chan KG, Lee LH (2014) Vibrio parahaemolyticus: a review on the pathogenesis, prevalence, and advance molecular identification techniques. Front Microbiol 5: 705.
Li P, Kinch LN, Ray A, Dalia AB, Cong Q, Nunan LM, Camilli A, Grishin NV, Salomon D, Orth K (2017) Acute hepatopancreatic necrosis diseasecausing Vibrio parahaemolyticus strains maintain an antibacterial type VI secretion system with versatile effector repertoires. Appl Environ Microbiol 83(13).

Li X, Zhou Y, Jiang Q, Yang H, Pi D, Liu X, Gao X, Chen N, Zhang X (2019) Virulence properties of Vibrio vulnificus isolated from diseased zoea of freshness shrimp Macrobrachium rosenbergii. Microb Pathog 127: 166-171.

Liu B, Liu H, Pan Y, Xie J, Zhao Y (2016). Comparison of the Effects of Environmental Parameters on the Growth Variability of Vibrio parahaemolyticus Coupled with Strain Sources and Genotypes Analyses. Front Microbiol, 7: 994.

Miyoshi S (2013) Extracellular proteolytic enzymes produced by human pathogenic Vibrio species. Front Microbiol 4: 339.

Nagpure A, Choudhary B, Gupta RK (2014) Chitinases: in agriculture and human healthcare. Crit Rev Biotechnol 34(3): 215-232.

Nishina T, Wada M, Ozawa H, Hara-Kudo Y, Konuma H, Hasegawa J, Kumagai S (2004) Growth kinetics of Vibrio parahaemolyticus O3:K6 under varying conditions of $\mathrm{pH}, \mathrm{NaCl}$ concentration and temperature. Shokuhin Eiseigaku Zasshi, 45: 35-7.

Ohishi K, Murase K, Ohta T, Etoh H (2000) Cloning and sequencing of a chitinase gene from Vibrio alginolyticus H-8. J Biosci Bioeng 89(5): 501-505.

Shinoda S (2011) Sixty years from the discovery of Vibrio parahaemolyticus and some recollections. Biocontrol Sci 16(4): 129-137.

Tran L, Nunan L, Redman RM, Mohney LL, Pantoja CR, Fitzsimmons K, Lightner DV (2013) Determination of the infectious nature of the agent of acute hepatopancreatic necrosis syndrome affecting penaeid shrimp. Dis Aquat Organ 105(1): 45-55.

Vermelho AB, Meirelles MN, Lopes A, Petinate SD, Chaia AA, Branquinha MH (1996) Detection of extracellular proteases from microorganisms on agar plates. Mem Inst Oswaldo Cruz 91(6): 755-760.

Vu NN, Hien PTT, Tien LNM, Chau DNP, Tung H, Nguyen TTH (2017) Investigating the production of extracellular enzymes of various Vibrio parahaaemolyticus isolates in Vietnam. J Biotechnol 15(4): 703-710. 
Wang R, Zhong Y, Gu X, Yuan J, Saeed AF, Wang S (2015) The pathogenesis, detection, and prevention of Vibrio parahaemolyticus. Front Microbiol 6: 144.

Whitaker WB, Parent MA, Naughton LM, Richards GP, Blumerman SL, Boyd EF (2010) Modulation of responses of Vibrio parahaemolyticus $\mathrm{O} 3: \mathrm{K} 6$ to $\mathrm{pH}$ and temperature stresses by growth at different salt concentrations. Appl Environ Microbiol 76(14): 4720-4729.
Xiong P, Peng X, Wei S, Chen Y, Zhao H, Tang S, Wu X (2014) Virulence-related genes of Vibrio alginolyticus and its virulence in mice. Wei Sheng $W u$ Хие Baо 54(1): 80-88.

Zhang C, Liang W, Zhang W, Li C (2016) Characterization of a metalloprotease involved in Vibrio splendidus infection in the sea cucumber, Apostichopus japonicus. Microb Pathog 101: 96103.

\title{
TÁC ĐỘNG CỦA NỔNG ĐỘ MUỐI VÀ ĐIỀU KIỆN LẤC TỚI SỰ PHÁT TRIỂN VÀ ĐỘC TÍNH CỦA VIBRIO PARAHAEMOLYTICUS
}

\author{
Trần Ngọc Mỹ Hạnh, Trần Vân Nhi, Nguyễn Thị Thu Hoài \\ Truòng Đại học Quốc tế, Đại học Quốc gia Thành phố Hồ Chí Minh
}

\section{TÓM TẮT}

Vibrio parahaemolyticus là vi khuẩn Gram - âm, ưa muối, rất phổ biến ở vùng nước mặn, nước lợ và ven biển. Vi khuẩn này là tác nhân chính gây hội chứng chết sớm hay còn gọi là bệnh hoại tử gan tụy cấp tính, gây ra thiệt hại lớn cho nuôi trồng tôm. Để phòng chống hiệu quả các đợt bùng phát bệnh do vi khuẩn này gây ra thì rất cần thiết có những hiểu biết về ảnh hưởng của môi trường sống tới sinh trưởng và độc tính của loài vi khuẩn này. Vì vậy, chúng tôi tiến hành nghiên cứu sự tác động của tốc độ lắc và các nồng độ muối khác nhau tới sự sinh trưởng và độc tính của $V$. parahaemolyticus. V. parahaemolyticus XN9 được nuôi cấy trong môi trường dinh dưỡng $\mathrm{BHI}$ chứa các nồng độ muối $2,0,2,5$ và $3,0 \%$ với các điều kiện lắc 0,120 và $240 \mathrm{rpm}$. Sự sinh trưởng của vi khuẩn được theo dõi trong 8 giờ và 6 chất tiết ngoại bào gồm caseinase, hemolysin, lecithinase, lipase, gelatinase và chitinase được phân tích sử dụng phương pháp khuếch tán đĩa thạch. Kết quả cho thấy, sự phát triển của $V$. parahaemolyticus bị tác động lớn bởi tốc độ lắc và nồng độ muối. Vi khuẩn sẽ phát triển tốt nhất ở điều kiện muối 2,0\% và lắc 240 rpm. Không có sự thay đổi lớn về các hoạt tính enzyme ngoại bào trong các điều kiện muối, ngoại trừ sự suy giảm đáng kể của enzyme gelatinase khi nồng độ muối tăng, thay đổi từ $3.49 \pm 0.19$ tới $2.77 \pm 0.17 \mathrm{~mm}(\mathrm{p}<0.05)$. Mặt khác, với tốc độ lắc, lipase là enzyme có sự tăng cường hoạt tính khi tốc độ lắc tăng lên $(\mathrm{p}<0.05)$. Trong khi các enzyme caseinase, lecithinase, gelatinase và lipase thể hiện hoạt tính tốt ở V. parahaemolyticus, hoạt tính hemolysin và chitinase lại không quan sát được ở chủng nghiên cứu. Như vậy, dữ liệu thu được cho thấy nồng độ muối $2,0 \%$ và tốc độc lắc $240 \mathrm{rpm}$ cung cấp điều kiện tối ưu cho sinh trưởng của $V$. parahaemolyticus và cho kết quả hoạt tính gelatinase và lipase cao nhất.

Từ khóa: Vibrio parahaemolyticus, bệnh hoại tử gan tụy cấp tính, độc lực, enzyme ngoại bào, nồng độ muối, sinh trưởng, tốc độ lắc 
Journal of Biotechnology 18(2): 349-362, 2020

\section{Supplementary figures}


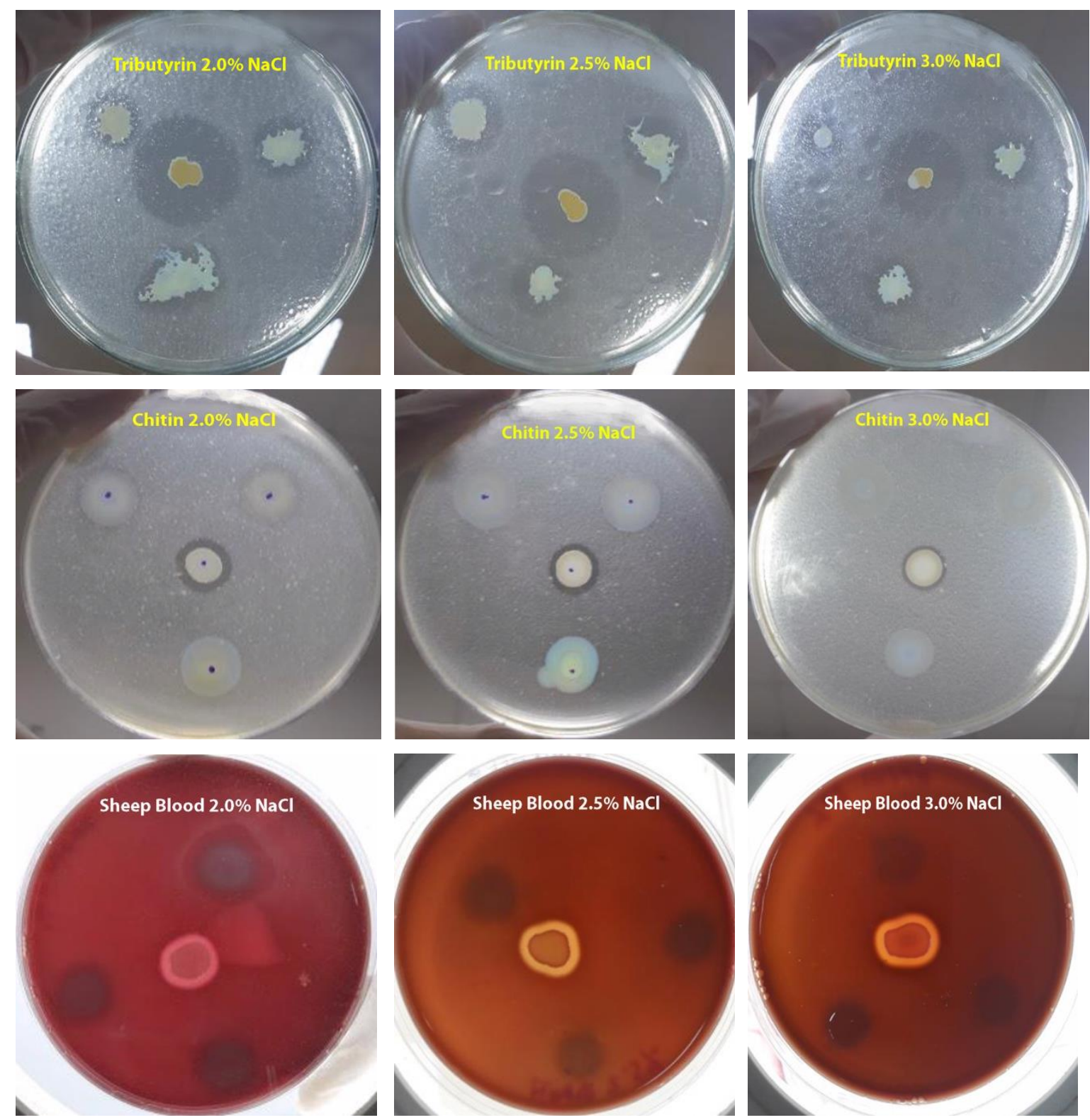

Figure S1. Effect of salinity on extracellular activity of $V$. parahaemolyticus. Representative images of agarbased testing for: from up to down: caseinase, gelatinase, lecithinase, lipase, chitinase and hemolysin; from left to right, $2.0 ; 2.5$ and $3.0 \% \mathrm{NaCl}$. On each agar plate, positive control is loaded in the middle surrounded by 3 technical replicated droplets of $V$. parahaemolyticus XN9. 
Journal of Biotechnology 18(2): 349-362, 2020
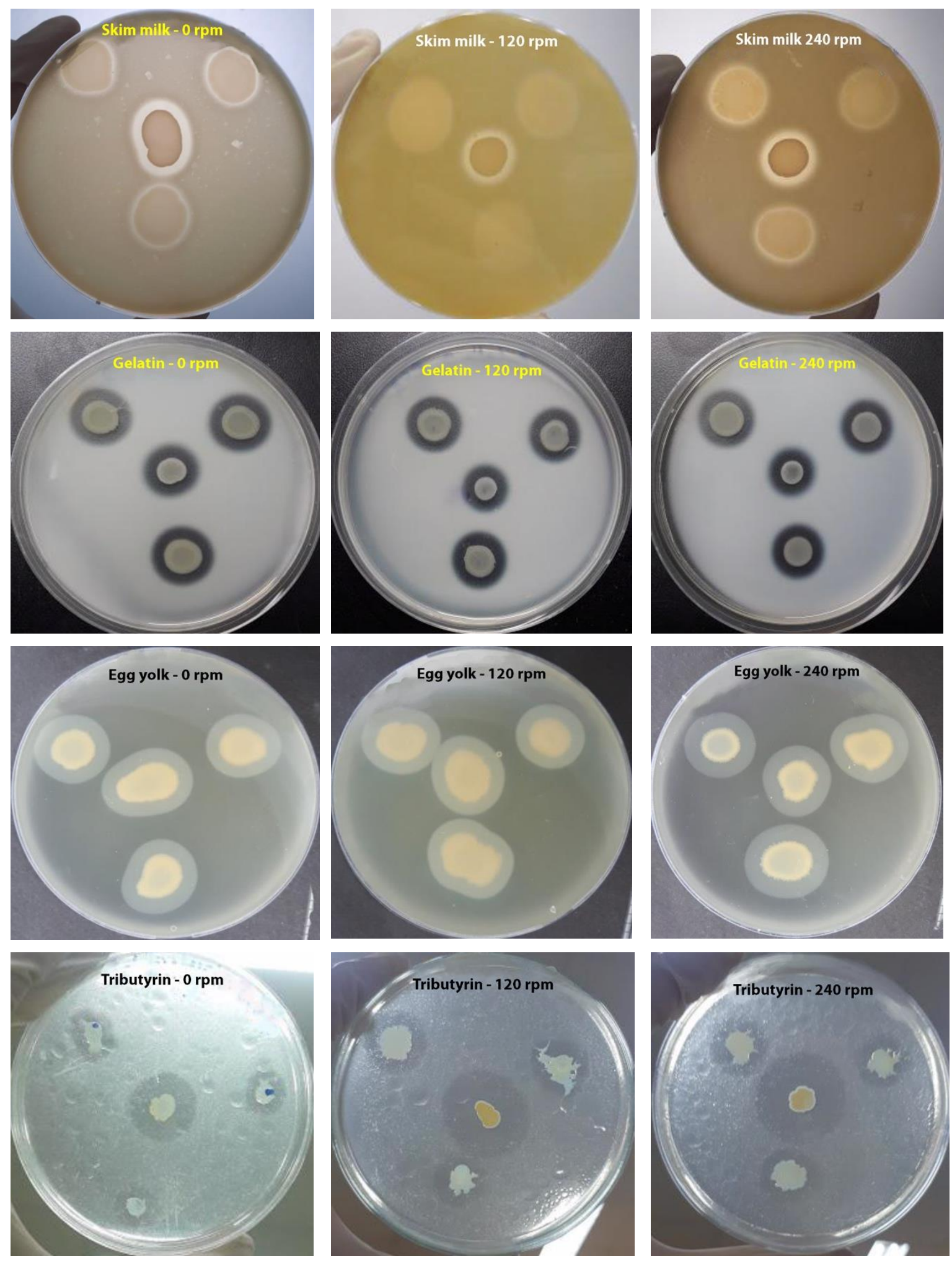
Tran Ngoc My Hanh et al.
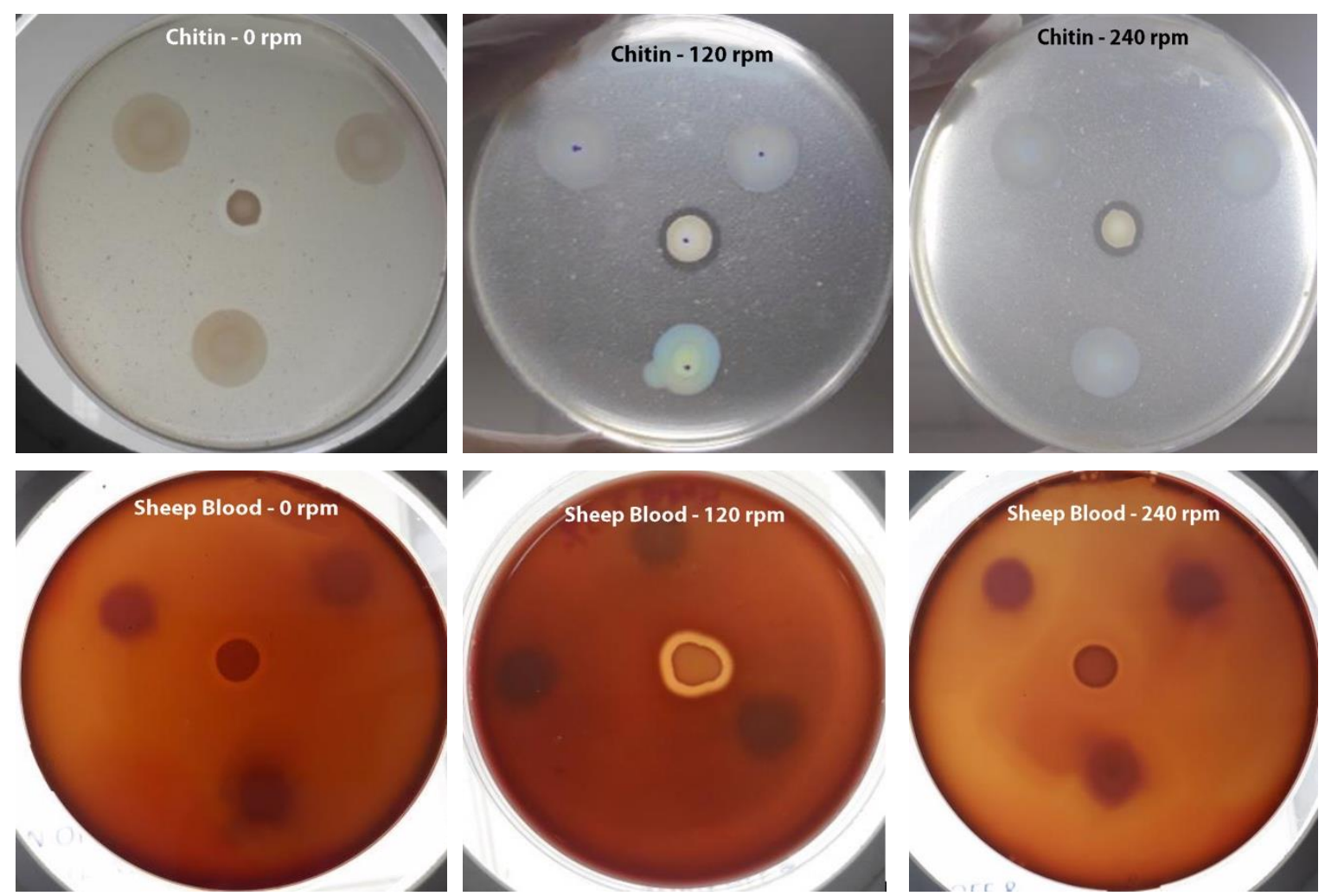

Figure S2. Effect of shaking speed on extracellular activity of $V$. parahaemolyticus. Representative images of agar-based testing for: from up to down: caseinase, gelatinase, lecithinase, lipase, chitinase and hemolysin; from left to right, $0 ; 120$ and $240 \mathrm{rpm}$. On each agar plate, positive control is loaded in the middle surrounded by 3 technical replicated droplets of $V$. parahaemolyticus XN9. 